This item was submitted to Loughborough's Research Repository by the author.

Items in Figshare are protected by copyright, with all rights reserved, unless otherwise indicated.

\title{
Behavioral foundations for open innovation: Knowledge gifts and social networks
}

PLEASE CITE THE PUBLISHED VERSION

http://dx.doi.org/10.1080/14479338.2016.1276406

\section{PUBLISHER}

(C) Taylor \& Francis

\section{VERSION}

AM (Accepted Manuscript)

\section{PUBLISHER STATEMENT}

This work is made available according to the conditions of the Creative Commons Attribution-NonCommercialNoDerivatives 4.0 International (CC BY-NC-ND 4.0) licence. Full details of this licence are available at: https://creativecommons.org/licenses/by-nc-nd/4.0/

\section{LICENCE}

CC BY-NC-ND 4.0

\section{REPOSITORY RECORD}

Dolfsma, Wilfred, and Rene Van der Eijk. 2019. "Behavioral Foundations for Open Innovation: Knowledge Gifts and Social Networks". figshare. https://hdl.handle.net/2134/23639. 


\section{Behavioral Foundations for Open Innovation:}

\section{Knowledge Gifts and Social Networks}

The innovation process has come to be seen as an interactive process where knowledge is continuously exchanged between individuals and actors internal and also external to a firm (Autio et al. 2004; Huizingh 2011; Landry et al. 2002). Innovation is, primarily, cooperative undertakings (Wuchty et al. 2007). Open Innovation (OI) plays an important role in innovation and will become increasingly important in the years to come (Chesbrough 2003a, b; Huizingh 2011). Open innovation involves knowledge being shared or exchanged with no or only limited contractual arrangements and no formal command and control relation between parties involved. ${ }^{1}$ In the generally accepted definition of OI ("'the use of purposive inflows and outflows of knowledge to accelerate internal innovation, and to expand the markets for external use of innovation, respectively'” Huizingh 2011, p.2) a defining feature of OI is that sharing knowledge occurs across firm boundaries (cf. Dahlander \& Gann 2012). Cooperation may be with other firms, some of its employees, or with customers (Bogers et al. 2010). This definition suggests that the flow of knowledge is the result of purposive behaviors by employees, following instructions of management, in effect seeing their behaviors being lined up with firm strategy. Individual employees involved in innovation activities, however, are in part and necessarily acting discretionary (Aalbers et al. 2014), and can as well show purposive OI behaviors that is not in line with firm strategy and perhaps in direct conflict with it (Ferrary 2003).

\footnotetext{
${ }^{1}$ In this paper we will use the terms knowledge exchange, knowledge transfer and knowledge sharing interchangeably.
} 
The behavioral dimensions of people sharing knowledge under such circumstances, especially across firm boundaries, are largely ignored: why would individuals share knowledge without a formal, contractual guarantee of some return? This conceptual paper argues that there is a need for a clearer understanding of the behavioral and motivational issues involved in knowledge sharing with a view to innovation, and offers suggestions to address this lacuna. Literature in psychology and on corporate citizenship indicates that motivational and behavioral issues can matter crucially if one is to understand success or failure of a (temporary) organizational form (Aalbers et al. 2013; Foss \& Lindenberg 2011; Organ 1990; Molm 2003), particularly when activities are extra-contractual and thus discretionary. Innovation activities, including OI activities, are at least in part discretionary, and thus not the direct result of formal instructions as part of someone's functionally defined role in an organization, provided by management. Some behaviors that ostensibly are to be characterized as open innovation behaviors, involving purposive knowledge transfer crossing firm boundaries, can, however, even be at odds with what somebody in a functional role is explicitly allowed to do (Ferrary 2003). The contribution this paper offers thus complements the more strategic issues in this discussion about open innovation (cf. Chesbrough 2003a, b; Henkel 2006).

Social exchange (of knowledge) does not necessarily happen by itself (Szulanski 1996), and may certainly have negative consequences as well (Gibney et al. 2009). A shifting 'locus of innovation' (von Hippel 2003b, p.39) will not leave the interactions between persons unaffected: how can the interactions they have within and across firm boundaries be understood? In particular, from a behavioral point of view: What explains why people are involved in the largely extra-role and not-contracted-for behavior of sharing knowledge? Social network analysis (SNA) offers insights into knowledge transfer as it explores network structure and network position (Allen, 1977; Allen and Cohen, 1969; Burt, 1992, 2004; Coleman, Katz, and Menzel, 1966; Gabbay and Zuckerman, 1998; Galunic and Moran, 2000; Hansen, 1999; Landry et al., 2002; Nahaphiet and Ghosal, 1998; Tushman, 1978; Tushman and Scalan, 1981). Social networks capture the important 
structural aspect of the cooperation involved in knowledge exchange. Social Network Analysis, however, purposefully ignores the motivational or behavioral dimension (see Aalbers et al. 2013; Obstfeld 2005). This behavioral dimension may be important for knowledge transfer too, however (Bouty 2000; Flyn 2003). The OI literature has a similar lack of attention to the behavioral or motivational aspects of individual knowledge transfer. We seek to suggest a way of combining insights from social network analysis with those from social exchange theory to address this shortcoming.

Several unanswered questions thus remain, but we focus on one: What micro processes are involved in sharing knowledge, particularly when knowledge sharing crosses firm boundaries (Darr et al. 1995; Felin \& Foss 2005; Henkel 2006; Kim \& Mauborgne, 1998; Tsai, 2001; von Hippel 1987; Obstfeld, 2005)? The “action problem” Obstfeld (2005) identified must be addressed: when, how and how much will people actually share knowledge, using the network structure that is there?

This article proceeds as follows. We first discuss aspects of knowledge relevant knowledge exchange. Social network literature is discussed to determine the extent to which it can be used to help explain knowledge sharing with reference to those characteristics of knowledge. Section 3 examines the 'action problem' that social network literature is rightfully claimed to have, which Section 4 addresses by introducing and developing the complementary notion of gift exchange. Section 5 then critically discusses literature on knowledge exchange by scientists in R\&D laboratories from this perspective, highlighting the added insight the combination of social network analysis and social (gift) exchange theory offers. Before we conclude (Section 7), Section 6 highlights some challenges for managers the argument in our paper suggests.

\section{Knowledge characteristics}

Schumpeter (1934) has famously claimed that innovation emerges from re-combining existing knowledge, in other words from sharing it among individuals. Burt (2004) has argued that new 
knowledge will develop from knowledge exchange, and is particularly likely to emerge at intersections where structural holes connect otherwise disconnected communities. Cooperation involving a number of interdependent actors who are able to specialize to a certain degree is in part what organizations are there for (Lopes \& Castro Caldas 2015). What people are involved in needs to be coordinated, and details of the content of the work must be shared for organizational benefits to become available. Knowledge exchange may be less obvious then the exchange of more tangible resources (Szulanski 1996). The exchange of innovative knowledge is different from that of other goods for a number of reasons that we will elaborate upon below, however (cf. von Krogh 1998). Importantly, the exchange of knowledge for innovation tends to be extra-role behavior in many cases (Organ 1990), and so not straightforwardly mandated by management or specified in a contract and thus open to discretion by the individual. We identify four characteristics of new knowledge or knowledge relevant for innovations which in particular affect the way in which it is transferred, and especially in the context of OI (cf. Von Krogh 1998).

- Developing new knowledge is, first of all, fraught with uncertainty (rather than mere risk), even when development of new technological knowledge is path-dependent. Uncertainty of a technological nature is well documented, but uncertainty of a strategic nature is involved as well. How much investment is needed, for how long? What market will there be for the products that may ultimately be designed based on new knowledge? Which competitors will be faced? Knowledge easily spills over unintentionally, and is in general a commodity the use and development of which is affected by opportunistic behavior of other parties, increasing associated transactions costs (Jones et al. 1997). If only characteristics and value of the knowledge yet to be developed is impossible to determine beforehand, contracting for the complete set of future scenarios that may ensue where the knowledge to be developed is involved in cannot be undertaken (Field, 2003; Hodgson 2005; Inkpen 1996; Starpoli 1998). 
- $\quad$ The process of knowledge generation and the resulting technological advance for the most part is, secondly, a cumulative process, where scientists draw on the work done by others, possibly in the past, and is generally based on the efforts of many inventors and developers (Mokyr 2002; Scotchmer 1991; Dolfsma \& Seo 2013). Knowledge generation requires that individuals have related knowledge; acquiring new knowledge at least initially involves tacit dimensions and may require coding and decoding (Dolfsma 2008a; Polanyi 1966). While newly developed knowledge is likely to be of a tacit nature, knowledge that developed in the past is more likely to be explicit. New knowledge needs integration into an existing larger framework of knowledge of the individual in which meaning is given to new piece of information. Actors find it easier to adopt and interpret knowledge that is "related” to their knowledge base (Hansen, 2002; Markides and Williamson, 1994). Accumulated stocks of knowledge are essential to the innovation development process, first as a resource to directly develop innovations, and, secondly as a basis for absorbing new knowledge (Cohen and Levinthal, 1990; Hansen, 2002; Markides and Williamson, 1994; Obstfeld, 2005; Powell et al. 1996). The literature on technological paradigms has argued that what holds for individuals also applies to groups of individuals, for instance involved in the development of a technological field (Dosi 1982; Mokyr 2002). Knowledge then, in the words of Isaac Newton, is developed while standing on the shoulders of giants (cf. Merton 1965).

- New knowledge is created in communities of practice, while the individuals interacting may or may not be members of the same organization (Bouty 2000; Brown and Duguid 1991, 2001; Nonaka 1994; Wenger \& Snyder 2000). Individuals in communities of practice may interact on a regular basis to solve problems, establishing mutual trust in the process (Knight 1967; Van der Eijk et al. 2009), building relationships of trust due to their affiliation and the engagement in common practices while sharing similar interests and/or expertise (Brown \& Duguid 1991; 2001; Wenger \& Snyder 2000; Wenger 1998). Communities of practice are repositories of social capital, with members trusting each other, facilitating exchange; they enable quick identification of and connection between individuals who have relevant knowledge. Communities of practice thus are 
"significant repositories for the development, maintenance, and reproduction of knowledge" (Brown \& Duguid 2001; cf. Lesser 2000), allowing individual members to solve problems and transfer best practices (Wenger 1998). Although co-location may be important for knowledge spillovers to occur (Dar et al. 1995; Decarolis \& Deeds 1999). Communities of practices can also span geographical distances (Agrawal et al. 2003; Brown \& Duguid 2001; Ensign 2009). Communities of practice tend to be associated with informal contacts between individuals (Dar et al. 1995; Furukawa \& Goto 2006; Park 2002).

- Knowledge is, fourth and finally, a (quasi) public good. It is non-exclusive: consumption or use by non-payers cannot be excluded without such means as intellectual property rights. Knowledge is also non-rivalrous: it is not consumed by its use (Alder 2001; Arrow 1984). “Information [thus] is costly to produce but cheap to reproduce” (Shapiro \& Varian 1999, p.21). This has strategic implications for firms, but for individuals within firms as well. As imitation or communication of knowledge can be easy and cheap, there is a tendency for these goods to be under-produced (Romer 2002). Information and knowledge are faced with an information paradox (Adler 2001; Arrow 1971): prior to the acquisition of information the value to the buyer cannot be established. If the potential buyer is allowed to inspect the good as a whole so as to determine its value to her, there no longer is a need for her to actually obtain it. As the product cannot be repossessed after the inspection, the seller may not be able to sell the good unless additional institutional arrangements such as Intellectual Property Rights are in place to provide exclusivity. Providing a sample of the good may mitigate the paradox, but only if the provider can be trusted to indicate exactly how representative the sample will be of the complete product. There will be a tendency for the provider to adversely select what to show the buyer. From an economics point of view, markets for knowledge fail inherently (Stiglitz 1994).

As a consequence of the characteristics of knowledge, its exchange between people is by no means an easy or self-evident process (Hansen 1999; Szulanski 1996), and likely to be extra-role for 
individuals involved due in large part to the characteristics of what is exchanged. For these reasons a number of scholars suggest that a more informal mode of governance for exchange and coordination, different from that of market or hierarchy, may best suit exchange of knowledge (Bradach \& Eccles 1989; Dore 1983; Hemetsberger \& Reinhardt 2009; Ouchi, 1980; Powell 1990). Table 1 presents a summary of this position - rather than discussing the characteristics of this informal, social exchange in general, we will focus on what form such exchange actually takes, and how it would functions in the context of knowledge exchange. This brings us to a discussion of the behavioral and motivational aspects of knowledge exchange, left largely unspecified in the literature so far. It is here that this paper contributes.

$<<$ Table 1 about here $>>$

Coordination mechanisms need not mutually exclude one another (Dolfsma et al. 2005), but innovative knowledge transfer is subject in large part to the third coordination mechanism. Even when trust and informal contacts thrive here, social relations importantly do have a structural aspect to them that literature in the Social Network analysis domain has explored.

\section{Social Network Literature}

A network is a set of relations linking nodes (e.g., people or organizations) (Knoke \& Kuklinski 1982; Scott, 1991; Wasserman \& Faust, 1994). Social network theory focuses on the position of nodes in the structure. Actors' behavior, it is assumed, is determined by the structure of the social network in which they are embedded. The position of actors in a network and type and number of ties determines the actors’ performance outcomes as well (Burt 1992; Hansen 1999). Social 
Network Analysis is increasingly recognized as a powerful perspective for studying innovation (Kastelle \& Steen 2010a ; Dolfsma \& Leenders 2016). ${ }^{2}$

Social network literature holds that while knowledge may reside in individuals, it is through networks that knowledge is exchanged and can be both put to use as well as developed further (Allen 1977; Coleman et al. 1966; Tushman 1978; Tushman \& Scanlan 1981). Network configurations and positions in the social network facilitate dissemination of information, and thus innovation. In line with what the literature on communities of practice suggests, social network theory indicates that, for instance, the shape of the network (its density, redundancy, clustering, size) (Allen and Cohen 1969; Tsai 2001) or the position of individuals (centrality, tie strength) (Hansen 1999; Granovetter 1973; 1982; Reagans \& McEvily 2003; Uzzi 1997) represent an important explanans for knowledge sharing and creation. In case of a low redundancy level, for instance, if more weak ties constitute the network, this stimulates a search for new ideas possibly from a more diverse set of sources. There may also be loosely related subgroups in a network of relatively many weak ties (cf. Granovetter 1973). Subgroups may be connected by structural holes that can exert great influence on the exchange (e.g. Burt 1992; 2004). “Closed” or cohesive networks, where redundancy is high, cannot easily be controlled by outsiders but are also less likely to have access to novel ideas, information and knowledge as the inflow of new ideas into a closed network is more limited than in a non-redundant network (Granovetter 1973). Such a network structure, usually marked by frequent communication and strong ties, does, however, offer actors the benefits of cooperative, coordinated action (Granovetter 1985; Obstfeld 2005) and the ability and willingness to exchange complex knowledge as a shared frame of reference and trust may more easily develop (Coleman 1988; Hansen 1999; Reagans and McEvily 2003; Uzzi 1997; Walker et al. 1997). Transfer of tacit knowledge, especially if of a sensitive nature, may require such close, personal interaction of individuals (Aalbers et al. 2016; Bouty 2000; Hansen 1999; Kogut and

\footnotetext{
${ }^{2}$ Note that in this paper we talk about relations between individuals only. In network analysis, nodes can also be different kinds of entities, such as events, artefacts, or locations, and a relation or tie between nodes need not signify knowledge transfer (Van der Valk \&Gijsbers; Aalbers \& Dolfsma 2015)..
} 
Zander 1992; Nonaka 1994; Polanyi 1966). Given the different strengths and weaknesses of the different network structures it is not surprising that research has taken a contingency approach emphasizing that different network structures are beneficial in different circumstances (e.g. Ahuja 2000; Podolny 2001; Rowley et al. 2000).

A network structure provides possibilities for actors to exchange with some actors and not with others (Skvoretz \& Lovaglia 1995). The structure of a network, in this view, determines with whom such extra-role behavior, 'above and beyond' what may be required of people, can be expected (Kastelle \& Steen 2010b; Zagenczyk et al. 2008), with some structures being better at promoting some kinds of activities over other activities (Ohly et al. 2010). Under-emphasizing the role of agency, social network literature suggests implicitly that the exchange of knowledge depends (only) on the 'pipes and prisms' of the network (Owen-Smith \& Powell 2004; Podolny 2001; Tsai \& Ghosal 1998). Acknowledging a role for strategic uncertainty due to agents’ behavior is problematic within the SNA framework (Foss et al. 2010). Opportunistic behavior on the part of actors in a network, as a result of which knowledge may not be freely shared, is inexplicable for SNA. Even in an otherwise trusting community (of practice), some individuals may be inclined to show behavior that undermines trust. Social network theory, focusing on the structure of relations only, cannot explain why relations emerge, change in nature, or end (see Van der Eijk et al. 2009). What may be claimed at most is that there is a tendency for certain kinds of behavior to be present in networks of a certain configuration. In closed, dense network, for instance, where all the nodes are mutually connected, the risk of opportunistic behavior may be lower due to emergence of enforceable norms (Coleman 1988; Portes \& Sensenbrenner, 1993) reputation effects (Coleman 1988; Ferrary 2003; Kreps 1990; Ostrom \& Ahn 2003; Sherry 1983) and repeat-interaction effect (Abreu 1998, Fudenberg \& Maskin 1986; Kreps et al. 1982). Actors properly connected, it is then assumed, will not be excluded from knowledge sharing; there will be no rivalry in knowledge sharing. 
From an SNA point of view, knowledge as a public good may be under-produced only if a network is not properly configured. How network structures emerge or evolve is not much addressed in SNA, however (Ahuja et al. 2012). Since SNA does not discuss the content of what is transferred using the networks, it cannot address the cumulative nature and inherent uncertainty of knowledge development. The difficulties of the diffusion and further development of knowledge reach beyond the structural elements of networks. However, while SNA theory has recognized the information and resource benefits of specifics of network structures, it has not focused on motivational or behavioral issues (cf. Hansen 1999; Moran \& Ghosal 1996; Van der Eijk et al. 2009). A more thorough understanding of the micro processes and behavioral foundations of socially sharing knowledge is needed (Darr et al. , 1995; Kim \& Mauborgne 1998; Obstfeld, 2005; Tsai 2001; see especially Felin \& Foss 2005 and Foss et al. 2010). Why actors share knowledge, or how relations get started, can be mobilized and coordinated, has received little attention (Van der Eijk et al. 2009). Obstfeld (2005) has, thus, claimed rightfully that SNA has an ‘action problem’.

\section{Action Problem}

Whenever individuals can achieve a common goal through cooperation, but each have other goals as well that are not (fully) aligned with the shared goal, a potential problem of (collective) action exists (Olson 1965, see also Randel \& Ranft 2007). As Huysman \& de Wit (2004) point out, due to the kind of good knowledge is, "knowledge sharing cannot be forced; people will only share knowledge if there is a personal reason to do so" (cf. Brown \& Duguid 1991; 2001; Szulanski 1996; Wenger \& Snyder 2000; Wenger 1998). Why do individuals, in the absence of clearly defined, formal, enforceable obligations, feel compelled to (continue to) provide others with knowledge? To achieve a mutually beneficial form of cooperation partially overlapping goals need to be aligned, addressing the motivational or behavioral dimensions of individuals' involvement in joint activities. When needs, interests or interpretations do not align and no way is found to address that, joint activities may not develop whatever structural connections are in place. This is what Obstfeld 
(2005) has dubbed the action problem for social network theory. The action problem may even be more pertinent in an OI setting where formal means to ensure knowledge exchange are absent to even indirectly have an effect (cf. Aalbers et al. 2014). Coordination through social relations is inevitable, but cannot be formally enforced, given what is exchanged in the context of OI relations. Referring to Figure 1, either a specific Alter (1A) or others one is more indirectly related to (AlterII; 1B) may but need not act in the expected manner since individual motivations or interpretations may prevent them from doing so (Uehera 1990). Interaction of the generalized type, (1C), may be least conducive to joint activity if interests do not align since not even an indirect structural connection exists between Ego and Y who reciprocates. In such a situation Ego may nonetheless initiate exchange in hopes of reciprocation and inclusion into a community (Ferrary 2003; Van der Eijk et al. 2009). In each of the three cases, reciprocation is not inevitable, however, even when a direct relation exists (Ekeh 1974; Ferrary 2003). As a result of the foregoing discussion, in case of Figure 1A, market, hierarchy as well as social relations type of coordination can be expected to work. In a situation that Figure 1B represents, however market coordination is not (less) likely to be effective. At the very least, market coordination of the classical kind using bilateral contracts no longer work unequivocally - other mechanism must be relied on (more). Other governance mechanisms can be those that are available in a hierarchy, or those that can be employed in social exchange situations. The situation portrayed in Figure 1C will require a variety of social interaction governance mechanisms to work.

Since SNA has focused exclusively on structural elements, it cannot assume what it in fact does assume: that the social capital and trust that may inhere in a network can be drawn on at will (cf. Coleman 1988, Van der Eijk et al. 2009). Due to socialization (Bauer et al. 2007), the alignment between group and individual motives may be larger between two individuals in a single organization when compared with individuals in different organizations. Since open innovation can and often does involve interactions between individuals from different organizations, the motivational challenges may be compounded. Coordinating intra- and inter-organizational 
collaboration, despite possibly conflicting goals and the possibility of opportunistic behavior, in the absence of coordination or regulation by external authority, does occur however (Ahuja 2000; Bouty 2000; Gulati \& Singh 1998). Informal routines are typically established to accomplish this. Understanding how these develop and are used provides behavioral or motivational micro foundations for knowledge sharing, particularly in an OI setting.

$<<$ Figure 1 about here $>>$

\section{Gift / Favor exchange}

For innovation it is clear that the flow of knowledge between agents within the same and across the boundaries of organizations is required. The flow of knowledge even within a single organization is far from obvious, however (Cross et al. 2001; Ghosal \& Barlett 1988; Hansen 1999; Kogut \& Zander 1992; Szulanski 1996). Knowledge may be present with actors in a network but not transferred for a number of reasons. Actors may not want to exchange knowledge, or may simply not know about the need that others have for their knowledge. The notion of sharing, conceptualized in the literature on gift exchange, provides an explanation of how actors are able to solicit the cooperation and exchange of knowledge from people within their network as well as from people beyond it (Bouty 2000; Dolfsma 2008b; Flynn 2003; Van der Eijk et al. 2009; Zeitlyn 2003). In the context of the extra-role behavior of knowledge transfer this argument has not been comprehensively made, nor were conceptual foundations developed.

Gift exchange theory offers insight into a wide variety of contexts (e.g. Akerlof 1982; Blau 1964; Heath 1976; Homans 1974). Gift exchange is sometimes, erroneously associated with the giving and receiving of explicit gifts on occasions such as birthdays, anniversaries, holidays and other special personal moments motivated by altruistic considerations only, but in actual fact is more encompassing. However significant in economic terms (Economist 2006), gift exchange is not limited to gifts in that sense. Informal relations of give \& take are pivotal in cooperation between 
firms (Uzzi 1997), even in markets where homogenous products are exchanged (Smart 1993), as well as within a firm (e.g. Ensign 2009).

Marcel Mauss (1954) and other anthropologists and ethnographers have made the point that the obligation to give, receive and reciprocate is universal, yet the way in which to give and what to give is context-dependent (Cheal 1986; Ekeh 1976; Sahlins 1996; Simmel 1996; Smart 1993). In a social, cultural context, institutions determine also when a gift is to be reciprocated (Van der Eijk et al. 2009). To the extent that gift exchange literature undergirds OI, one would expect inbound OI not to persist without outbound OI: in actual fact, over time, the two would be connected inseparably, even if conceptually distinct for some analytical purposes (Dahlander \& Gann 2012).

A mixture of motives is involved in gift exchange, including altruism, power and selfinterest (Blau 1964; Ekeh 1974; Malinowski 1996; Mauss 1954). Smart (1993) points out that the exchange partners can but need not be aware of the instrumental goals involved. Both the possibly instrumental goals involved as well as the perceived value of a gift must ostensibly be ignored by the parties involved (Beltramini 1996; Bourdieu 1992). This is an important reason for favor or gift exchange to be ritualized (Khalil 2004). If actors fall short of expectations about giving and reciprocating, the particular dyadic exchange relationship may be terminated and excommunication from the wider social network may follow (Mauss 1954; Van der Eijk et al. 2009): “individual aggressiveness is curbed by the prospect of ostracism among peers, in both trade and social circumstances” (Williamson 1975, p.107). Mauss (1954) has argued in this context that people are required to (1) give, (2) receive, as well as (3) reciprocate (Dore 1983; Gouldner 1960; Levi-Strauss 1996; Malinowski 1996; Sahlins 1996; Schwartz 1996; Simmel 1996), at least with peers (Ferrary 2003). Not being involved in gift exchange means one is not (yet) seen as a worthy peer, or one has violated context specific routines or rituals of exchange.

Most resources can be gifts, as gifts may be defined as those goods, material or immaterial, including knowledge, feedback and tips, given to an alter in the expectation that it will be accepted and reciprocated at some point. Gift exchange needs to be out-of-balance at any moment in time so 
that it is clear that a relation will continue in the future. Because gift exchange is unbalanced when viewed at one point in time, a longitudinal perspective reveals the nature of gift giving: a gift is not reciprocated by an immediate return or compensation (Bourdieu 1977; Deckop et al. 2003; Ferrary 2003; Mauss 1954). A deferred return-gift obligates one individual to another, creating social debt. Reciprocity is open to discretion as to the value and form of the counter-gift; the nature of the compensation is not specified beforehand and highly context-dependent (Bourdieu 1977; Deckop et al. 2003; Gouldner 1960; Mauss 1954; Zaidman \& Brock 2009). Specifying obligations a priori may prompt an abrupt end to the relation, yet not giving any specifications at all about the nature of the exchange may allow for misinterpretation or abuse of the situation. Gift exchange is carried out without a legal contract (Ferrary 2003), but even so it creates an informal obligation (Gouldner 1960; Levi-Strauss 1996; Malinowski 1996; Mauss 1954; Sahlins 1996; Schwartz 1996; Simmel 1996). Gift giving confers benefits of an economic and a social nature simultaneously (Belk 1979; Larsen \& Watson 2001). Gift exchange is, however, not only an economic transaction providing economic (material) benefit, it is also a good in itself, a 'process benefit', in the sense of sustaining personal relationships (Avner 1997). Relations between giver and receiver may become increasingly personal and are an important dimension of many transactions. They then come to have a value independent of their instrumental functions in regulating transactions (Rose-Ackerman 1998). The notion of gift exchange thus explains how relations are established, maintained, or may discontinue (Belk 1979; Cheal 1988; Gouldner 1960; Larsen \& Watson 2001; Mauss 1954; McGrath \& Englis 1996; Ruth et al. 1999; Sherry 1983).

As a corollary of the cycle of giving, receiving and reciprocating, obligations, as well as trust and gratitude are generated between the (exchange) parties involved (Belk \& Coon 1993 Blau 1964; Euhara 1990; Gouldner 1960; Sahlins 1996; Mauss 1954). Gift exchange is associated with the generation of positive emotions and uncertainty reduction which generates cohesion and commitment (Homans 1958; Ingram and Robert, 2000; Lawler et al. 2000). Frequent gift or favor exchange is associated with the creation of trust facilitating further cooperation (Coleman 1988; 
Fukuyama 1995; Nooteboom 2002; Putnam 1993), and establishes a common frame of reference, lowering associated risk and uncertainty between parties, and establishing partners' trustworthiness (McAllister 1995; Shapiro 1987; Smith Ring \& van de Ven, 1992). This process allows Ego to make inferences about both competence and intentional trust in Alter (Nooteboom 2002). What may have started out as a mostly goal oriented interaction may become embedded over time in social relations (Granovetter 1985; Uzzi 1997), in part because individuals strive to derive a sense of pleasure or intrinsic satisfaction from their interactions (du Gay 1996; Eccles 1981).

"Gifts can be described as an investment in the relationship between donor and recipient. The greater the value of the gift, the more substantial the investment” (Larsen \& Watson; 2001). These investments are not only necessary since connections are not givens but require work (Bourdieu 1977, 1986), but also expedient since they can purposively yet carefully be used to (try to) create social obligations (Bourdieu 1977; Burt 1992; Coleman 1988, 1994; Darr 2003; Granovetter 1985; Kotter 1985; Mauss 1954; Walton and Mckersie 1969; Yukl and Falbe 1991). By the same token, if alters are indebted to ego, he can use this as a basis for entitlement to future support (Coleman 1988, 1994; Mauss 1954). Given that these obligations are social, noncontractual and legally unenforceable, actors cannot draw on them at will, however. Failing to reciprocate, nonetheless, will effectively prevent ongoing profitable exchanges but can also mean excommunication from the relevant group (Barney \& Hansen 1994 from Rose-Ackerman 1998; Ferrary 2003; Van der Eijk et al. 2009; Williamson 1975).

The literature on gift exchange is rightly placed in the broader context of social exchange theory (Ekeh 1974), and so the explanation we offer for knowledge transfer in an open innovation context complements, we believe, the analyses of OI offered by others (von Hippel 1987; Lakhani \& von Hippel 2003). As gift exchange not only transfer utility but also is socially meaningful interaction embedded in relations of mutual dependence and obligation, it contributes to the willingness to transfer knowledge (Camerer 1988; Cheal 1986). Especially when exchange involves uncertainties and interdependencies that can by definition not be fully foreseen and contracted for 
will social coordination through gift exchange be the coordination mechanism of choice. This is evident from the discussion of corporate scientists sharing knowledge: as knowledge develops cumulatively in the context of a community of practice, understanding what drives knowledge sharing is of some import.

\section{Knowledge Sharing, Gifts, and Engineers}

Considering the uncertainty and social dimensions related to knowledge development, market contracts or direction in a hierarchy may not, in all cases, lead to the desired result of knowledge exchange. Knowledge sharing can be largely extra-role or discretionary. In the context of the development of open source software, this already is readily acknowledged (Henkel 2006; von Hippel 1987; Lakhani \& von Hippel 2003). In this section we show how the mechanisms of gift exchange we have elaborated upon above play a role in knowledge sharing (Darr 2003; Sjostrand 2004). Gift exchange, not necessarily fully voluntary but nevertheless extra-role in many instances is driven by obligations of a social and informal nature, as argued. Gift exchange, involving altruistic as well as more self-interested motives, provides the parties involved with a mechanism for the exchange of resources as well as with incentives to do so especially in the kind of circumstances where both interdependencies and uncertainty are substantial as is the case for knowledge development. Social obligations stemming from gift exchange and the network position taken can be employed to elicit future support (Coleman 1988) for instance to obtain the further knowledge that is needed (Bouty 2000; Darr 2003; Ensign 2009; Humphrey \& Hugh-Jones 1992). Reciprocal gift exchange establishes a transactional relationship between individuals (Sherry 1983) and allows actors to forge and personalize relationships and to develop guarantees of personal bonding (Shapiro 1987; Zucker 1986). As these relationships develop and the exchange interactions progresses actors learn to cooperate with these particular others (Gulati 1995; Powell et al. 1996; Starpoli 1998) and establish a common frame of reference allowing actors to incorporate new, possibly complex and tacit knowledge (Hansen 1999; Kogut and Zander 1992; Von Hippel 1994). 
As actors thus bridge ‘cognitive distance’ (Nooteboom 2002) “tacit or personal knowledge which is anchored on the commitment of and beliefs of its holder” (Nonaka 1994) can be interpreted and acted upon.

In studies looking at what determines the success that some corporate laboratory scientists have and others lack some noteworthy findings emerge. Those who actively engage in the publication of papers, giving to the scientific community at large, are more successful at developing knowledge than those who don't (Bouty 2000). This is, obviously, partly due to the fact that this is a means for them to be up-to-speed with the most recent developments in their fields, keeping their own and their organization's absorptive capacity high (Cohen \& Levinthal 1990). There is more to this, however. These scientists claim themselves that they also receive more from others, working elsewhere, formally and informally, in the form of access to scientists in other organizations and unpublished or tacit knowledge (Furukawa \& Goto 2006; Hicks 1995). Most of the knowledge at the frontier of advanced research may be tacit (Hicks 1995); such knowledge will only be shared with researchers whom one has established a longer term relationship of trust and understanding with, a relationship of strong ties (Hansen 1999). Corporate scientists, creating goodwill and establishing obligations 'by building a relationship of give and take with the scientific community' (Hicks 1995), can act as technological gatekeepers and serve as a bridge between external sources of knowledge and their co-workers. This active behavior in publishing of some scientists in an organization boosts their effectiveness within their own organizations as well. The resulting flow of knowledge encourages innovation in which they themselves and their co-workers are involved, thereby benefiting the organization as whole (Furukawa \& Goto 2006).

The story of corporate scientists cooperating informally through gift exchange continues. Bouty (2000) has shown that lab scientists can be involved in relations with scientists they know in other, sometimes competing, organizations, helping each other out in ways that may sometimes counter explicit organizational regulations, and if abused by alters could seriously hurt ego’s organization. Still, with specific others, laboratory tests, feedback, hints and the like are exchanged. 
Gifts are offered, received and reciprocated. The element of limited circulation of gifts in a trusted circle of peers is clear: if a person is not known, no gifts are exchanged; if a person is not known well, gifts of low value such as commonly available knowledge is exchanged; if a person is known well and for a long time very valuable and highly sensitive knowledge can get to be exchanged. Indeed, contrary to expectations from economic theory, opportunities to exchange are not seized if ego knows that alter could just as well engage with others (Ensign 2009, p.106). Also, rare and valuable knowledge is more likely to be shared than common and easily obtainable knowledge provided that "assurances that [return gifts] will follow” are there (ibid.). Such assurances are not contractually enforced or mandated, and so failure to reciprocate will hurt ego. Exchange opportunities are preferably entered into that give rise to more substantial returns some unspecified time in the future. In each of these cases, of course, no formal guarantee of a counter-gift, of equal value, is available. Opportunism remains possible at all times, but would lead to excommunication and a loss of reputation. In gift exchange actors do evaluate the value of knowledge exchanged, especially in case of enhanced uncertainties and (strategic) interdependencies involved when crossing organizational boundaries (Bouty 2000; von Hippel 1987; Kreiner \& Schultz 1993). These relations between corporate scientists within and between firms involved in exchanging knowledge is not an uncommon phenomenon (see Allen 1977; Kreiner \& Schultz 1993; Von Hippel 1987; Brown \& Duguid 1991, 2001;Wenger \& Snyder 2000; Wenger 2001), but has not been provided with proper behavioral micro foundations. Although we argue that such micro foundations are to be found in the gift exchange literature, we do acknowledge that the social coordination of knowledge sharing dynamics through gift exchange offers challenges for managers.

\section{Challenges for Management of Coordination through Gift Exchange}

While exchange of gift provides a stimulus for the flow of knowledge, attempting to purposefully coordinate this by providing directed incentives for knowledge sharing does present specific challenges for management. Firstly, gift exchange for the most part takes place between concrete 
individuals, who may establish idiosyncratic rituals and expectations. It may be hard to formulate formal policy to stimulate this kind of activity. Secondly, for gift exchange to personalize, relations that may guarantee reciprocation need to develop over an extended period of time. One also is only able to initiate and maintain so many relationships in a given period of time (Lesser 2000), and developing each relation to the necessary level of trust takes time too. Thirdly, social obligations established through gift exchange cannot usually be enforced and so actors are most likely to coordinate knowledge exchange via gift exchange when other options are not sufficient, too inflexible, too time-consuming or otherwise impractical (Ferrary 2003; Smart 1993). Knowledge transfer through gift exchange is to some extent vulnerable from abuse. Fourthly, gift exchange effectiveness in part depends on the extent to which the incentive structure of an organization can be altered in such a way that honoring social debts and cooperation becomes an effective course of action for the individual. The effectiveness of social enforcement mechanisms can be impaired if the likelihood or benefit of continued informal cooperation is small (Kreps 1990), or if the network structure is such that subsequent action cannot be monitored or communicated thus limiting the effectiveness of reputations (Coleman 1988; Hill 1990; Lazaric \& Lorenz 1998). Fifthly, gift exchange obviously has no bearing on situations were knowledge is intentionally sought and nonvoluntary or unknowingly obtained. Knowledge acquisition by means of hacking, reverse engineering, industrial espionage or “outlaw innovation” (Flowers 2008) clearly do not fit the gift exchange model. Finally, while organizations generally strive to maximize knowledge flows within organizational boundaries or into the organization, they are likely to try to minimize knowledge flows across organizational boundaries. While spillover effects are pervasive (Audretsch \& Feldman 1996; Feldman 1999; de Laat 1999; Owen-Smith \& Powell 2004), they are not only associated with formal cooperative arrangements between firms but also with informal personalized exchange between knowledge workers (e.g. Allen 1977; Agrawal et al. 2003; Kreiner \& Schultz 1993; Von Hippel 1987). While, it is evident that companies need to preserve core competencies (cf. Henkel 2006), there is a danger that organizations attach to much weight to appropriability 
considerations, neglecting the dynamic of new knowledge creation and knowledge flows between firms and other social entities that they may also benefit from in the end (Chesborough 2003a, b; Nooteboom 2002; Saxenian 1994; von Hippel 1987). As a result of too strict a policy of spill-over control the firm might hamper the innovation development process (Soh 2010). Those actors that do not give do not receive in return either.

\section{Conclusion}

Innovativeness of individuals and firms is largely dependent on people within and beyond the firm exchanging knowledge and information. Social Network Analysis (SNA) allows an analysis of the structure of interactions within a firm: how do interactions affect behavior of actors within a firm and ultimately firm performance? Given the nature of knowledge and its development, discussed in Section 2 above, however, the issue of why actors would actually use their relations for these purposes remains a mystery for SNA. SNA has an ‘action problem’ as it does not allow for agency. The need for behavioral micro foundations for knowledge exchange is especially needed in the context of Open Innovation.

The notion of gift exchange allows one to explain why persons exchange knowledge with each other even if they are not obliged to by contract or instruction. Gifts can be non-material to include knowledge and are exchanged for multiple reasons, but especially provide a means of control in case of interdependencies and uncertainties. The literature of gift exchange explains how mutual trust and informal obligations between persons emerge, and allows one to understand how relations start, work and come to an end. We have argued how gift exchange offers a powerful and necessary complement to the insights that Social Network Analysis offers. Especially for OI, research has shown how researchers involved in gift exchange are more successful as researchers. Thus we offer a perspective for the discussion on 'open innovation' that complements the more strategic discussions by offering behavioral micro foundations for the processes of socially sharing knowledge within and between organizations. 


\section{References}

Aalbers, H.L., W. Dolfsma \& O. Koppius (2014) "Rich Ties and Innovative Knowledge Transfer within a Firm” British Journal of Management 25(4): 833-848.

Aalbers, H.L., W. Dolfsma \& R. Leenders (2016) "Vertical and Horizontal Cross-Ties: Benefits of CrossHierarchy and Cross-Unit Ties for Innovative Project Teams” Journal of Product Innovation Management 33(2): 141-153.

Aalbers, H.L. \& W. Dolfsma(2015) Innovation Networks. London \& New York: Routledge.

Abreu, D. (1988) 'On the Theory of Infinitely Repeated Games with Discounting.’, Econometrica 56(2): 383-396.

Adler, P.S. (2001) 'Market, Hierarchy, and Trust: The Knowledge Economy, and the Future of Capitalism' Organization Science 12(2): 215-234.

Adler, P.S., and Kwon, S.W. (2002) ‘Social capital’ Academy of Management Review 27(1): 17-40.

Agrawal, A. K., Cockburn, I. M., \& McHale, J. (2003) “Gone but not forgotten: Labor flows, knowledge spillovers, and enduring social capital” Journal of Economic Geography 6(5): 571-591.

Ahuja, G. (2000), ‘Collaboration Networks, Structural Holes, and Innovation’ Administrative Science Quarterly 45: 425-455.

Ahuja, G., G. Soda \& A. Zaheer (2012) “The Genesis and Dynamics of Organizational Networks” Organization Science 23(2): 434-448

Akerlof, G.A. (1982) ‘Labor Contracts as Partial Gift Exchange’ Quarterly Journal of Economics 97: 543569.

Allen, T.J. (1977) Managing the flow of technology. Cambridge MA: MIT Press.

Allen, T.J., and Cohen, S.I. (1969) 'Information flow in research and development laboratories' Administrative Science Quarterly 14: 12-19.

Arrow, K.J. (1984) 'Information and economic behavior’, In: Collected Papers of Kenneth J. Arrow, Vol.4., Belknap Press, Cambridge, MA.

----, (1971) Essays in the Theory of Risk Bearing. Markham, Chicago, IL.

Audretsch, D.B. and M.Feldman (1996) "R\&D spillovers and geography of innovation and production” American Economic Review 86(3): 630-640.

Autio, E., Hameri, A. and Vuola, O. (2004) ‘A framework of industrial knowledge spillovers in big-science centers’ Research Policy 33: 107-126.

Avner, O. (1997) 'Between the Gift and the Market’ Economic History Review 50(3): 450-476.

Baer, T.N., T. Bodner, B. Erdogan, D.M. Truxillo \& J.S. Tucker (2007) “Newcomer adjustment during 
organziational socialization” Journal of Applied Psychology 92(3): 707-721.

Belk, R. (1979) ‘Gift-Giving behavior’, In: Research in Marketing Volume 2, Ed. Sheth, J., Greenwich, CT:, JAI Press

Belk, R.W., and Coon, G.S. (1993) “Gift Giving as Agapic Love” Journal of Consumer Research 20: 393417.

Beltramini, R.F. (1996) 'Business believes in Gift Giving’, In: Gift Giving: A Research Anthology, Eds. Otnes, C. \& Beltramini, R.F., Bowling Green: Bowling Green State UP.Biggart, N.W. \& R. Delbridge (2004) ‘Systems of exchange’ Academy of Management Review 29(1):, 28-49.

Blau, P. (1964) Exchange and Power in Social Life. New York: Wiley.

Bogers, M., A. Afuah \& B. Bastian (2010) Users as Innovators: A Review, Critique, and Future Research Directions” Journal of Management 36(4): 857-875.

Bourdieu, P. (1992) The Field of Cultural Production. Cambridge: Polity Press.

----, (1986) 'Forms of Capital', In: Handbook of Theory and Research for the Sociology of Education., Ed. Richardson, J. G. , New York: Greenwood Press.

----, (1977) Outline of a Theory in Practice. Cambridge UP: Cambridge.

Bouty, I. (2000) 'Interpersonal and interaction influences on informal resource exchanges between R\&D researchers acrros organizational boundaries’ Academy of Management Journal 43(1): 50-65.

Bradach, J.L. and Eccles, R.G. (1989) ‘Market versus Hierarchies’ in R.Th.A.J. Leenders and S.M. Gabbay (eds), Corporate Social Capital and Liability, Dordrecht: Kluwer, pp.97-118.

Brown, J.S. and Duguid, P. (1991) 'Organizational Learning and Communities of Practice’ Organization Science 2(1): 40-57.

----, (2001) ‘Knowledge and Organization’ Organization Science 12(2): 198-213.

Bugental, D. B. (2000) 'Acquisition of the Algorithms of Social Life: A Domain-Based Approach', Psychological Bulletin 126(2): 187-219.

Burt, R.S. (1992) Structural holes: The social structure of competition. Cambridge, MA: Harvard UP.

----, (2004) 'Structural Holes and Good Ideas’ American Journal of Sociology 110: 442-455.

Camerer, C. (1988) 'Gifts as Economic Signals and Social Symbols’ American Journal of Sociology 94: 180-214.

Cheal, D. (1986) ‘The Social Dimensions of Gift Behaviour’ Journal of Social and Personal Relationships 3: 423-439.

Chesbrough, H. (2003a) Open Innovation. Harvard Business School Press.

----, (2003b) “The Logic of Open Innovation: Managing Intellectual Property” California Management Review 45(3): 33-58.

Cohen, W.M., and Levinthal, D.A. (1990) ‘Absorptive capacity’ Administrative Science Quarterly 35: 128152. 
Coleman, J.S. (1994) Foundations of Social Theory. Cambridge MA: Belknap Press.

----, (1988) 'Social Capital in the creation of Human Capital’ American Journal of Sociology 94 (Suppl.): S95-S120.

Coleman, J.S., Katz, E., and Menzel, H. (1966) Medical Innovations. Indianapolis: Bobbs-Merrill.

Cross, R., Parker, A., and Borgatti, S. (2001),'Knowing what we know: Supporting knowledge creation and sharing in social networks’ Organizational Dynamics 30(2): 100-120.

Dahlander L. \& D.M.,Gann (2010) “How open is innovation?” Research Policy 39: 699-709.

Darr, A. (2003) 'Gifting Practices and Inter-organizational Relations’ Sociological Forum 18(1): 31-51.

Darr, E.D., Argote, L., and Epple, D. (1995) “The Acquisition, Transfer, and Depreciation of Knowledge in Service Organizations” Management Science 41(11): 1750-1762.

Decarolis, D.M., and Deeds, D.L. (1999) “The Impact of Stocks and Flows of Organizational Knowledge on Firm Performance” Strategic Management Journal 20(10): 953-968.

Deckop, J.R., Cirka, C.C., and Andersson, L.M. (2003) 'Doing Unto Others: The Reciprocity of Helping Behavior in Organizations’ Journal of Business Ethics 47: 101-113

Dolfsma, W. (2008a) Knowledge Economies. London: Routledge.

----, (2008b) “Making Knowledge Work” Knowledge Organization 35.

Dolfsma, W., J. Finch \& R. McMaster (2005) “Market and Society: (how) do they relate, and contribute to welfare?” Journal of Economic Issues 39(2): 347-356.

Dolfsma, W. \& D. Seo (2013) “Government Policy and Technological Innovation - A suggested typology” Technovation 33(6-7): 173-179.

Dolfsma, W. \& R. Leenders (2016) “Social Networks for Innovation and New Product Development” Journal of Product Innovation Management 33(2): 123-131.

Dore, R. (1983) “Goodwill and the spirit of market capitalism” British Journal of Sociology 34(4): 459-482.

Dosi, G. (1982) “Technologial Paradigms and Technological Trajectories” Research Policy 11: 147-162.

Du Gay, P. (1996) Consumption and Identity at Work. London: Sage.

Eccles, R.G. (1981), ‘The quasifirm in the construction industry’ Journal of Economic Behavior \& Organization 2(4): 335-357.

The Economist (2006) The business of giving. February 25.

Eijk, R. van der, W. Dolfsma and A. Jolink (2009) “On a source of social capital: gift exchange” Journal of Business Ethics 89(3), pages 315-329.

Ekeh, P.P. (1974) Social Exchange Theory: the two traditions. London: Heinemann.

Ensign, P.C. (2009) Knowledge Sharing among Scientists. New York: Palgrave Macmillan. 
Feldman, M.P. (1999) ‘The new economics of innovation, spillovers and agglomeration’ Economics Innovtion \& New Technology 8: 5-25.

Fellin, T. and N.J. Foss (2005) "Strategic organization: a field in search of micro-foundations" Strategic Organization 3(4): 441-455.

Ferrary, M. (2003) 'The Gift Exchange in the Social Networks of Silicon Valley’ California Management Review 45(4), 120-138.

Field, J. (2003) Social Capital. London and New York: Routledge

Fiske, A.P. (1992) 'The Four Elementary Forms of Sociality: Framework for a Unified Theory of Social Relations', Psychological Review 99(4): 689-723

Flowers, S. (2008) 'Harnessing the Hacker; The Emergence and Exploitation of Outlaw Innovation' Research Policy 37(2), 177-193.

Flynn, F.J. (2003) "How much should I give and how often? The effects of generosity and frequency of favor exchange on social status and productivity” Academy of Management Journal 46(5): 539-553.

Foss, N. and S. Lindenberg. 2011. Managing Motivation for Joint Production: The Role of Goal Framing and Governance Mechanisms. Academy of Management Review 36(3): 500-525.

Fudenberg, D., and Maskin, E. (1986) 'The Folk Theorem in Repeated Games with Discounting or with Incomplete Information’ Econometrica 54(3): 533-554.

Fukuyama, F. (1995) Trust, the Social Virtues and the Creation of Prosperity. New York: Free Press.

Furukawa, R. and A. Goto (2006) “The role of corporate scientists in innovation” Research Policy 35: 24-36.

Gabbay, S.M., and Zuckerman, E.W. (1998) ‘Social capital and opportunity in corporate R\&D’ Social Science Research 27(2): 189-217.

Galunic, C., and Moran, P. (2000) ‘Social capital and productive exchange’ Working Paper Insead 1: 1-31.

Ghoshal, S. and Bartlett, C.A. (1988) 'Creation, adoption, and diffusion of innovations by subsidiaries of multinational corporations’ Journal of International Business Studies 19: 365-388.

Gibney, R., T.J. Zagenczyk and M.F. Masters (2009) “The Negative Aspects of Social Exchange: An Introduction to Perceived Organizational Obstruction” Group \& Organization Management 34(6): 665-697.

Gouldner, A.W. (1960) “The Norm of Reciprocity” American Sociological Review 25: 161-178.

Granovetter, M.S. (1973) ‘The Strength of Weak Ties’ American Journal of Sociology 78, 1360-1380.

----, (1985) "Economic Action and Social Structure" American Journal of Sociology 91(Nov): 481-510.

Gulati, R. (1995) “Does familiarity breed trust” Academy of Management Journal 38: 85-112. 
Gulati, R. and P.Lawrence (1998) ‘The architecture of cooperation’ Administrative Science Quarterly 43: 781-814.

Hansen, M.T. (2002), 'Knowledge networks: Explaining effective knowledge sharing in multiunit companies’ Organization Science 13(3): 232-248.

----, (1999) “The Search-Transfer Problem” Administrative Science Quarterly 44(1): 82-111.

Heath, A.F. (1976) Rational Choice and Social Exchange. Cambridge UP.

Hemetsberger, A. and C. Reinhardt (2009) “Collective Development in Open-Source Communities: An Activity Theoretical Perspective on Successful Online Collaboration” Group \& Organization Management 30(9): 987-1008.

Henkel, J. (2006) “Selective revealing in open innovation processes: The case of embedded Linux” Research Policy 33: 953-969.

Hicks, D. (1995) "Published papers, tacit competencies and corporate management of the public/private character of knowledge”, Industrial and Corporate Change 4(2): 401-424.

Hill, C.W.L. (1990) Cooperation, opportunism and the invisible hand” Academy of Management Review 15(3): 500-513.

Hodgson, G.M. (2005) ‘Knowledge at Work’ Review of Social Economy 60(4): 547-65.

Homans, G.C. (1974) Social Behavior. New York: Harcourt Brace Jovanoviech.

----, (1958) ‘Social Behavior as Exchange’ American Journal of Sociology 63: 597-606.

Humphrey, C and S. Hugh-Jones (1992), Barter, Exchange and Value, Cambridge, UK Cambridge UP.

Huysman, M. and D. de Wit (2004) 'Practices of Managing Knowledge Sharing” Knowledge and Process Management 11(2): 81-92.

Ingram, P. and P. Roberts (2000) ‘Friendship among Competitors in the Sydney Hotel Industry’ American Journal of Sociology 106(2): 387-423.

Inkpen, A.C. (1996) ‘Creating Knowledge through Collaboration’ California Management Review 39(1): 123-140.

Jones, C., Hesterly, W.S., and S.P. Borgatti (1997) 'A general theory of network governance: Exchange conditions and social mechanisms’ Academy of Management Review 22(4): 911945.

Kastelle, T. \& J. Steen (2010a) “Using Network Analysis to Understand Innovation” Innovation: Management, Policy \& Practice 12(1): 2-4.

Kastelle, T. \& J. Steen (2010b) “Are small world networks always best for innovation?” Innovation: Management, Policy \& Practice 12(1): 75-87.

Khalil, E. (2004) "The Gift Paradox: Complex Selves and Symbolic Good" Review of Social Economy 62(3): 379-392. 
Kim, W.C. and R. Mauborgne (1998) 'Procedural Justice, Strategic Decision Making, and the Knowledge Economy’ Strategic Management Journal 19(4): 323-338.

Knight, K.E. (1967) ‘A Descriptive Model of the Intra-Firm Innovation Process’ Journal of Business 40(4): 478-496.

Knoke, D., and J.H. Kuklinski (1982) Network Analyses, Newbury Park, CA : Sage.

Kogut, B., and Zander, U. (1992) 'Knowledge of the Firm, Combinative Capabilities, and the Replication of Technology' Management of Technology 3(2): 383-397.

Komter, A.E. (1996) The Gift: An Interdisciplinary Approach. Amsterdam: Amsterdam UP.

Kotter, J. (1985) Power and Influence. Free Press, New York

Kreiner, K., and M. Schultz (1993) “Informal Collaboration in R\&D” Organization Studies 14(2): 189-209.

Kreps, D., Milgrom, P., and Wilson, R. (1982) ‘Rational Cooperation in the Finitely Repeated Prisoner’s Dilemma', Journal of Economic Theory 27: 245-252.

Kreps, D.M. (1990) 'Corporate culture and economic theory', In: Perspectives on Political Economy, Eds. Alt, J and Shepsel, K., Cambridge UP.

Laat, P.B. de ( 1999) 'Dangerous liaisons: Sharing knowledge within R\&D alliances’, In: Interfirm Networks, Organizations and Industrial Competitiveness, Eds Grandori, A., London: Routledge.

Lakhani, K.R. and E. Von Hippel (2003) "How open source software works: ‘free’ user-to-user assistance” Research Policy 32: 923-943.

Landry, R., Amara, N., and Lamari, M. (2002) 'Does social capital determine innovation? To what extent?' Technological Forecasting and Social Change 69: 681-701.

Larsen, D. and Watson, J.J. (2001) ‘A Guide Map to the Terrain of Gift Value’ Psychology \& Marketing, 18(8), 889-906.

Lawler, E., Thye, S., and Yoon, J. (2000) ‘Emotion and group cohesion in productive exchange’ American Journal of Sociology 106: 616-657.

Lazaric, N. and E. Lorenz (1988), ‘Corporate Social Capital’, In: Corporate Social Capital and Liability, Eds. R.Th.A.J. Leenders and S.M. Gabbay, Dordrecht: Kluwer: 1-14.

Lesser, E.L. (ed) (2000), Knowledge and Social Capital. Butterworth Heinemann: Boston.

Levi-Strauss, C (1996) 'The principle of reciprocity’, In: The Gift: An Interdisciplinary Perspective, Ed. Komter, A.E. , Amsterdam: Amsterdam UP.

Lopes, H. and J. Castro Caldas (2015) “Firms: collective action and its supportive values” in: W. Dolfsma and J. Davis (eds) Elgar Companion to Social Economics, $2^{\text {nd }}$ edition. Cheltenham: Edward Elgar.

McAllister, D.J. (1995) 'Affect- and cognition based trust as foundations for interpersonal cooperation in organizations’ Academy of Management Journal 23: 262-288. 
McGrath, M.A. and B. Englis (1996) 'Intergenerational Gift Giving in Sub-cultural Wedding Celebrations’, In: Gift Giving: A Research Anthology. Eds. Otnes, C. and Beltramini, R.F., Bowling Green: Bowling Green State UP.

Malinowski, B. (1996) ‘The Principle of Give and Take’ In: The Gift: An Interdisciplinary Perspective, Ed. Komter, A.E., Amsterdam: Amsterdam UP.

Markides, C., and P. Williamson (1994) 'Related diversification, core competencies and corporate performance', Strategic Management Journal 15: 149-167.

Mauss, M. (1954) [2000], The Gift. New York: Norton.

Merton, R.K. (1965) On The Shoulders of Giants. Free Press.

----, (1968) "The Matthew Effect in Science” Science 159: 56 - 63

Mokyr, J. (2002) The Gifts of Athena - Historical Origins of the Knowledge Economy. Princeton, NJ: Princeton UP.

Molm, L.D. (2003) 'Theoretical Comparisons of Forms of Exchange’, Sociological Theory 21(1): 1-17

Moran, P., and Ghosal, S. (1996) 'Value creation by firms', Academy of Management Proceedings, 35-39.

Nahapiet, J., and Ghosal, S. (1998) 'Social capital, intellectual capital, and the organizational advantage', Academy of Management Review, 23(20), 242-266.

Nonaka, I. (1994) ‘A Dynamic Theory of Organizational Knowledge Creation’ Organization Science 5(1): 14-37.

Nonaka, I., and Takeuchi, H. (1995) The Knowledge-Creating Company. New York: Oxford UP.

Nooteboom, B. (2002) Trust. Cheltenham: Edward Elgar.

Obstfeld, D. (2005) ' Social Networks the Tertius Lungens Orientation, and Involvement in Innovation', Administrative Science Quarterly, 50, 100-130.

Ohly, S., R. Kase \& M. Skerlavaj (2010) “Networks for generating and for validating ideas: the social side of creativity” Innovation: Management, Policy \& Practice 12(1): 41-52.

Olson, M. (1965) The Logic of Collection Action. Cambridge, MA: Harvard UP.

Organ, D. W. (1990). The motivational basis of organizational citizenship Behavior. Research in Organizational Behavior 12: 43-72.

Ostrom, E. and T. K Ahn. (2003) Foundations of Social Capital, Northhampton: Edward Elgar.

Ouchi, W.G. (1980) 'Markets, bureaucracies, and clans’ Administrative Science Quarterly 25 (1): 129-141.

Owen-Smith, J. and Powell, W.W. (2004) 'Knowledge Networks as Channels and Conduits' Organization Science 15 (1): 5-21.

Park, S.O. (2002) ‘Regional innovation strategies in the knowledge-based economy’ GeoJournal 53(1): 2938. 
Podolny, J.M. (2001) 'Networks as the Pipes and Prisms of the Market’ American Journal of Sociology 107(1): 33-60.

Polanyi, M. (1966) The Tacit Dimension, New York: Anchor Day Books.

Portes, A. and J. Sensenbrenner (1993) 'Embeddedness and immigration: notes on the social determinants of economic action’ American Journal of Sociology 98: 1320-1350.

Powell, W. (1990) “Neither market nor hierarchy: Network forms of organization,” Research in Organization Behavior 12: 295-336.

Powell, W.W., Koput, K.K., and L. Smith-Doerr (1996) 'Inter-organizational collaboration and the locus of innovation’ Administrative Science Quarterly 41: 116-145.

Putnam, R.D. (1993) Making Democracy Work. Princeton, NJ: Princeton UP.

Randel, A.E. and A.L. Ranft (2007) "Motivation to Maintain Social Ties With Coworkers - The Moderating Role of Turnover Intentions on Information Exchange” Group \& Organization Management 32(2): 208-232.

Reagans, R. and McEvily, B. (2003) 'Network Structure and Knowledge Transfer’ Organization Science 13(3): 232-248.

Romer, P. (1992) "When should we use intellectual property rights”, Monthly Review, 54(8), 29-37.

Rose-Ackerman, S. (1998) 'Bribes and Gifts’, In: Economics, values and organization, Eds. Ben-ner, A and Putterman, L., Cambridge UP.

Rowley, T., Behrens, D., and Krackhart, D. (2000) “ Redundant governance structures” Strategic Management Journal 21, 369-386.

Ruth, J.A., Otnes, C.C., and F.F Brunel. (1999) 'Gift receipt and the reformulation of interpersonal Relationships', Journal of Consumer Research 25(4): 385-402.

Rothwell, R., Freeman, C., Horlsey, A., Jervis, V.T.P., Robertson, A.B., and Townsend, J. (1974) “SAPPHO Updated - Project SAPPHO Phase 2” Research Policy 3: 259-91.

Sahlins, M, D. (1996), ‘On the Sociology of Primitive Exchange”, In: The Gift: An Interdisciplinary Perspective, Ed. Komter, A.E., Amsterdam: Amsterdam UP.

Saxenian, A. (1994) Regional Advantage: Culture and Competition in Silicon Valley and Route 128. Cambridge, MA: Harvard UP.

Schumpeter, J. (1934 [1978]) The Theory of Economic Development. London; Oxford UP.

Schwartz, B. (1996) 'The Social Psychology of the Gift', In: The Gift: An Interdisciplinary Perspective, Ed. Komter, A.E., Amsterdam: Amsterdam UP.

Scotchmer, S. (1991) "Standing on the Shoulders of Giants: Cumulative Research and the Patent Law" Journal of Economic Perspectives 5(1): 29-41.

Scott, J. (1991) Social network analyses. London: Sage.

Shapiro, S.P. (1987) 'The social control of impersonal trust' American Journal of Sociology, 93: 623-658 
Shapiro, C. and H.R. Varian (1999) Information Rules. Harvard Business School Press: Boston Massachusetts.

Sherry, J.F. (1983), 'Gift Giving in Anthropological Perspective’ The Journal of Consumer Research, 10(2), 157-168.

Simmel, G. (1996) 'Faithfulness and Gratitude’, In: The Gift: An Interdisciplinary Perspective, Ed. Komter, A.E., Amsterdam: Amsterdam UP.

Sjostrand, G. (2004), 'The modern gift institution in industrial districts', Economic Sociology, 5(3).

Skvoretz, J. and Lovaglia, M.J. (1995) ‘Who Exchanges with Whom’ Social Psychology Quarterly 58: $163-177$.

Smart, A. (1993) ‘Gifts, Bribes, and Guanxi’ Cultural Anthropology 8(3): 388-408.

Smith Ring, P. and van de Ven, A. (1992) 'Structuring cooperative relationships between organizations' Strategic Management Journal 13: 483-498.

Soh, P.-H. (2010) "Network Patterns and Competitive Advantage before the Emergence of a Dominant Design” Strategic Management Journal 31: 438-461.

Starpoli, C. (1998) 'Cooperation in R\&D in the pharmaceutical industry' Technovation 18(1): 13-23.

Stiglitz, J.E. (1994) Wither Socialism? Cambridge: MIT Press.

Szulanski, G. (1996) ‘Exploring internal stickiness’ Strategic Management Journal 17: 27-43.

Tsai, W. and Ghosal, S. (1998) ‘Social Capital and Value Creation’ Academy of Management Journal 41(4): 464-476.

Tsai, W. (2001) 'Knowledge transfer in intra-organizational networks' Academy of Management Review 44: 996-1004.

Tushman, M.L. and T.J. Scanlan (1981) "Boundary spanning individuals” Academy of Management Journal 24: 289-305.

Tushman, M.L. (1977) ‘Special boundary roles in the innovation process’ Administrative Science Quarterly 22: 587-606.

Uehara, E. (1990) 'Dual Exchange Theory, Social Networks, and Informational Support', The American Journal of Sociology, 96: 521-557.

Uzzi, B. (1997), 'Social Structure and competition in inter firm networks’ Administrative Science Quarterly 42(1): 35-67.

Van der Vak, T. \& G. Gijsbers (2010) “The use of social network analysis in innovation studies: mapping actors and technologies” Innovation: Management, Policy \& Practice 12(1): 5-17.

Von Hippel, E. (1994) “'Sticky information’ and the locus of problem solving” Management Science 40(4): 429-439.

----, (1987) ‘Cooporation between rivals: Informal know-how trading’ Research Policy 16: 291-302. 
Von Krogh, G. (1998) “Care in Knowledge Creation” California Management Review 40(3): 133-153.

Walker, G., Kogut, B., and Shan, W. (1997) 'Social capital, structural holes and the formation of an industry network’ Organization Science 8: 109-125.

Walster, E., Berscheid, E., and Walster, G.W. (1973) ‘New Directions in Equity Research’ Journal of Personality and Social Psychology 25(2): 151-176.

Walton, R. and McKersie, R. (1969) A Behavioral Theory of Labor Negotiations, McGraw-Hill, New York.

Wasserman, S., and Faust, K. (1994) Social Network Analysis. Cambridge, England: Cambridge UP.

Wenger, E.C., and Snyder, W. (2000) 'Communities of Practice the Organizational Frontier’ Harvard Business Review 139-145.

Wenger, E.C. (1998) Communities of Practice. Cambridge: Cambridge UP.

Williamson, O,E., (1985) The Economic Institutions of Capitalism. New York: The Free Press.

----, (1975) Markets and Hierarchies. New York: Free Press.

Wuchty, S., B. Jones \& B. Uzzi (2007) "The Increasing Dominance of Teams in the Production of Knowledge," Science, May, 316:1036-9.

Yukl, G., and Falbe, C.M. (1991) 'Influence tactics and objectives in upward, downward and lateral relations' Journal of Applied Psychology 76: 416-423.

Zagenczyk, T.J., R. Gibney, A.J. Murrell and S.R. Boss ( 2008) “Friends Don’t Make Friends Good Citizens, But Advisors Do” Group \& Organization Management 33(6): 760-780.

Zaidman, N. and D.M. Brock (2009) “Knowledge Transfer Within Multinationals and Their Foreign Subsidiaries - A Culture-Context Approach” Group \& Organization Management 34(3): 297-329.

Zeitlyn, D. (2003) “Gift economies in the development of open source software: anthropological reflections” Research Policy 32(7): 1287-1291.

Zucker, L.G. (1986) 'Production of trust: Institutional sources of economic structure, 1840-1920.' Research in Organizational Behavior 8: 53-111. 